\title{
MUNKA, GAZDASÁG ÉS ERKÖLCS II. JÁNOS PÁL PÁPA TANÍTÁSÁNAK FÉNYÉBEN
}

\section{LABOUR, ECONOMICS AND MORALS IN THE LIGHT OF THE TEACHING OF POPE JOHN PAUL II}

\author{
Erdő Péter \\ az MTA doktora, bíboros, esztergom-budapesti érsek \\ Esztergom-Budapesti Főegyházmegye
}

\section{ÖSSZEFOGLALÁS}

A munka erkölcsi értékelése II. János Pál pápa tanításának fényében a gazdaság működésének erkölcsi értékelése keretében lehetséges. Ennek során a teljes emberképből kell kiindulni, amely az embert nem csupán a fogyasztás és a termelés tényezőjeként, hanem tudatos szabad és méltósággal rendelkező lényként fogja fel. Az erkölcsi felelősség megállapítását ma rendkívül megnehezíti a viszonyok bonyolultsága. A természettudományok fejlődése nyomán a közvéleményben az a kép alakul ki, hogy gazdasági tevékenységünk hatásait teljesen soha nem tudjuk felmérni. Ez pedig a felelősségérzetet kérdőjelezi meg. Az informatikai társadalom a formális logikai fogalmakra, ítéletre és következtetésre alapuló minősítési mechanizmusa helyett gyakran az erős manipulatív hatásokra való és a tudatos választást megkerülő reakciókra hajlamos. Mégis lehetséges a szimbolikus kommunikáció magasabb szintjén a bonyolult tényállásokra való sajátos etikai reflexió.

\section{ABSTRACT}

Moral evaluation of labour in the light of the teaching of John Paul II is possible within the frame of moral evaluation of the working of economics. The starting point should be the entirety of man which considers man not only as a factor of production and consumption, but as a conscious free being with dignity. The ascertainment of moral responsibility is made harder by the complexity of relations. As a cause of the development of the natural sciences the public thinks that we can never measure the full effects of our economic activities. This questions the sense of responsibility. The society of IT often apt to reactions of strong manipulative effects and of those which avoid the conscious choice, instead of the rating mechanisms of formal logic based on concepts, judgements and deductions. Still there is a possibility of a particular moral reflection for the complex matters of fact on a higher level of symbolic communication.

Kulcsszavak: etika, ember, II. János Pál, munka, felelősség, informatika

Keywords: ethics, man, Pope John Paul II, labour, responsibility, IT 
A munkáról az Egyház hosszú története során számos megnyilatkozás született. Eleinte fóként a Biblia erre vonatkozó kijelentéseit elmélkedték át, vagy egy-egy konkrét kérdésre, például a rabszolgaság intézményére vagy a túlzott luxusra reagáltak. A középkorban sem született azonban a munkával kapcsolatos átfogó teológiai elmélet. Az újkor folyamán azután szaporodtak az ezzel kapcsolatos teológiai fejtegetések, a pápai megnyilatkozások szintjét azonban mindez csak a 19-20. század fordulóján érte el. Hangsúlyt kaptak az ezzel kapcsolatos teológiai alapelvek, a teremtésben való együttmüködés, az ember kötelessége a munkára, a munkához való jog és más szempontok. A 20. század folyamán az Egyház tanításában is előtérbe került annak felismerése, hogy a munka benne áll a gazdaság és a társadalom összefüggésében, ugyanakkor pedig az emberi méltóság kifejezése. Ilyen értelemben jelentett szintézist és fordulópontot II. János Pál pápa Laborem exercens kezdetủ enciklikája, melyet a Rerum novarum 90 . évfordulójára adott ki (II. János Pál, 2005a, 135-186.).

\section{MILYEN SZEMPONTBÓL FOGLALKOZIK A GAZDASÁGGAL AZ EGYHÁZ?}

A kereszténység hosszú története során mind a teológia, mind az egyházfegyelem síkján, mind pedig a hívő közösségek életében gyakran megjelentek olyan kérdések, amelyeket ma gazdasági jellegüeknek tekintünk. Ezek sorában visszatérö, kiemelkedő jelentőségü és sokat tárgyalt téma volt például a kamat, illetve a kamatszedés tilalmának kérdése. Ugyanakkor azonban hiába keresnénk részletesen kidolgozott gazdasági elméleteket az Egyház belső történetében. Maga Jézus nem a gazdasági sikeresség módszerét tanította, s az Egyház sem tekintette feladatának, hogy ilyen értelemben vett gazdaságtudománnyal foglalkozzék. Ezek a problémák mindig erkölcsi vonatkozásban merültek fel. Mindig az volt a kérdés, hogy az emberi cselekvés mikor felel meg a teremtő és megváltó Isten akaratának. Manapság a teológusok leginkább az Egyház társadalmi tanításának keretében foglalkoznak a gazdaság problémáival. Ez a tanítás pedig az erkölcsteológia területére tartozik, annak - sajátosan bonyolult tárgyára tekintettel - napjainkra meglehetősen önállóvá vált részét alkotja.

A gazdasággal kapcsolatos egyházi felfogás bemutatásának megkönnyítése végett a gazdaság szó háromféle értelmét szokás megkülönböztetni: „,a gazdaságot mint tudományt, mely a gazdagodásra irányuló viselkedéseket és azoknak egy egész rendszerbe való integrálódását vizsgálja; a gazdaságot mint bizonyos alanyok (egyének, vállalkozások, szervezetek, állam) tevékenységét; és a gazdaságot mint gazdasági rendszert, vagyis olyan intézményeket és szabályokat, amelyeknek keretében az alanyok tevékenysége folyik" (Duchini, 2004, 280.). A gazdaság fenti három értelme egymással szervesen összefüggő valóságokat jelöl, ám a vizsgálat szempontjából mégis meg szokás különböztetni őket. Az itt említett má- 
sodik és harmadik jelentés elsősorban a tényekhez és nem annyira az elméletekhez kötődik. Éppen ezért az Egyház társadalmi tanítása elsősorban ezekre reagál.

A gazdaság léte számára mindenesetre előfeltétel az a tény, hogy az emberi élet társadalmi formációkban, csoportokban folyik. A köztudatban leginkább ott jelenik meg problémaként a gazdasági tevékenység, ahol a javak, szolgáltatások létrehozása, elosztása vagy a közös tevékenység megszervezése kapcsán nézeteltérésekre kerül sor, illetve ahol az ilyen müködéssel kapcsolatos intézmények hívják fel magukra a figyelmet.

\section{A KÖZGAZDASÁG MINT TUDOMÁNY AZ EGYHÁZ TÁRSADALMI TANÍTÁSÁNAK FÉNYÉBEN}

A 19. század közepéig az Egyház tanításában a gazdaságtudomány egészével szemben egyfajta bizalmatlanság volt megfigyelhető. A gondolkodásnak a gazdaságban érvényesülő módja ugyanis pusztítónak, veszélyesnek és megtévesztőnek tünt (vö. Duchini, 2004, 280.). Így a keresztény gondolkodók arra éreztek hivatást, hogy a társadalmi, gazdasági valóságot, annak müködését az igazságos társadalom építésének távlatába állítsák (vö. Duchini, 2004, 280.). XIII. Leó pápa Rerum novarum kezdetủ enciklikájában azonban olyan utalásokat is megfogalmazott (44. és 45. pont), amelyek bátorították a tudományos eszmecserét a társadalmi, gazdasági területen is, mégpedig a szaktudományok autonómiájának elismerésével (vö. Duchini, 2004, 280.). A közgazdaság-tudomány katolikus művelöi azonban viszonylag korán érzékeltek magában a szaktudományban is bizonyos világnézeti előfeltevéseket, amelyek szerintük kritikára szorultak. Mindenekelőtt az ember túlzottan individualista felfogását bírálták, továbbá a társadalom materialista jellegű szemléletét, melyben a javak azonosítása vagy meghatározása elsősorban hedonista nézőpontból történik. Azt is észrevételezték, hogy a gazdaságtudomány világán belül nem talál a szakma eszközöket a saját filozófiai kiindulópontjának, különösen a fent említett egyoldalúságoknak a korrigálására (Duchini, 2004, 280.). A két világháború közti időben aztán a keresztény reflexió - elismerve a közgazdaság-tudomány jelentős eredményeit - törekedett az egész gazdasági tevékenység céljának megvilágítására. Ahogyan XI. Piusz pápa a Quadragesimo anno kezdetü enciklikájában (43. pont) (magyarul XI. Piusz, é. n., 70. n. 43.) hangsúlyozta, a gazdaságban is müködik az emberi szabadság, döntéseket hoz az ember, ezeknek pedig a teremtő Istentől megjelölt célra kell irányulniuk. Végső soron egy teljesebb emberkép alapján értelmezett közjót kell szolgálniuk (vö. Duchini, 2004, 280.).

A II. Vatikáni Zsinat Gaudium et Spes kezdetü rendelkezésében (36. pont) (II. Vatikáni Zsinat, 1975, 446-509., 465. n. 36.) már azt hangsúlyozza, hogy a tisztességes, tudományos kutatás sosem kerül valódi ellentmondásba a hittel, mert az evilági realitás és a hitben megragadott valóság egyaránt Istentől ered. Vannak 
tehát a teremtett dolgoknak és magának a társadalomnak is saját törvényei. Ezeket az embernek fel kell fedeznie és használnia kell, mégpedig rendezett módon, a Teremtő akaratának megfelelően (vö. II. Vatikáni Zsinat, 1975, 446-509., 465. n. 36.). És itt érkezünk el a gazdaság és erkölcs viszonyának alapvető megállapításához, nevezetesen annak felismeréséhez, hogy a gazdasági életben tevékeny ember is valódi emberi cselekvéseket végez, vagyis tudatos és szabad. Nem csupán élettelen csavar egy elvont logika szerint müködő, az embertől független, mintegy matematikai gépezetben, hanem lehetősége és feladata, hogy felelősen válassza meg céljait és az azokhoz vezető eszközöket. Tehát akárcsak a politikában, a gazdaságban is minden ellenkező látszattal szemben igaz, hogy az ember felelős a tetteiért, hogy az erkölcs hatálya az életnek ezekre a területeire is kiterjed. Tehát nem szolgáltathatjuk ki a politikát az embertől elvonatkoztatott hatalom logikájának éppúgy, ahogyan a gazdaságot sem az embertől, az emberi élettől elvonatkoztatott, matematikainak látszó törvényszerüségek puszta működésének. Ha ez valahol mégis megtörténik, akkor előbb-utóbb a klasszikus értelemben vett elidegenedés valósul meg, amelynek következménye társadalmi kataklizma lehet. Az Egyház társadalmi tanítása felhívja a figyelmet arra, hogy a piac, ha figyelmen kívül hagyja a társadalmi hasznosságot, és csak a vállalkozó nyereségét tekinti célnak, „embertelen és elidegenült berendezkedés létrejöttét teszi lehetővé” (Az Igazságosság és Béke Pápai Tanácsa, 2007, 183. n. 348.).

\section{A GAZDASÁG MINT TEVÉKENYSÉG AZ EGYHÁZ TÁRSADALMI TANÍTÁSÁBAN}

Amikor a gazdaság és erkölcs viszonyát vizsgáljuk, a gazdasági tevékenységet nem mint puszta tárgyi valóságot tekintjük, melyhez az ember erkölcsileg különféleképpen viszonyulhat, mint mondjuk az anyagi javakhoz, hanem úgy szemléljük, mint emberi cselekvések összességét. Hiszen a gazdasági tevékenység, bár sokszor úgy érezhetjük, hogy az egyes emberek egyéni döntéseitől szinte független, öntörvényủ valóság, valójában tudatos és szabad emberi cselekvésekből tevődik össze. Ezért van helye a gazdasági cselekvésekkel kapcsolatban is a felelösségnek, ezért nem lehet a gazdaságot puszta öntörvényü technikának felfogni, mellyel kapcsolatban bizarrnak vagy érzelgősnek tünhetne a moralizálás. A gazdaság annyiban van alávetve az erkölcsi megítélésnek, amennyiben emberi cselekvésekböl áll, vagyis teljes egészében.

A Quadragesimo anno hangsúlyozza, hogy a gazdasági tevékenység nem a legföbb jó és nem az egyetlen cél, hanem alárendelt eszköz, amely Isten tervében kap értelmet és üdvösségre segítő értéket (43. pont). Tehát a gazdasági tevékenységet a maga sajátos törvényszerüségei és módszerei szerint kell folytatni, de az erkölcsi rend keretében oly módon, hogy megfeleljen annak a tervnek, amelyet maga Isten alkotott az emberről (II. Vatikáni Zsinat, 1975, 486. n. 64.). Mint annyiszor, itt is 
az emberkép, az ember fogalma, az ember valósága a központi kérdés. Amíg nem válaszoltunk meg arra, hogy ki az ember, azt is csak töredékesen és esetlegesen tudjuk megítélni, hogy mi a jó az embernek, hogy mit értünk például az életkörülmények javításán. Miközben tehát az ember maga és családja megélhetéséért dolgozik, arra kell törekednie, hogy tevékenysége a társadalom javát is szolgálja. Ezzel hozzájárul Isten tervének kibontakozásához a történelemben (II. Vatikáni Zsinat, 1975, 486. n. 34.). A II. Vatikáni Zsinat által meghirdetett nemes eszmény hátterében világos teológiai megfontolások rejlenek. Mégis sajátos színt ad nekik a hatvanas évek összefüggésrendszere, az a közhangulat, amely optimista módon hitt a haladásban, és úgy vélte, hogy a természettudományok és a technika fejlödése itt, a földön mindenki számára megszerzi a lehetö legnagyobb boldogságot. A fejlődés határtalanságának ez az illúziója, valamint a fejlődésnek a mennyiségi növekedéssel való kimondatlan azonosítása azonban hamarosan kijózanodáshoz vezetett. A nyersanyagok és energiahordozók kimerülésének lehetőségét, a környezetszennyezés problémáját egyre élénkebben érzékeli az emberiség. Ugyanakkor egyre inkább megjelenik a köztudatban az a felismerés is, hogy a tudatos emberi tevékenység olyan természeti rendszereket és müködéseket érint, amelyeket csak részben ismerünk. Újra érezhetjük a varázslóinas ijedelmét, aki esetleg olyan erőket szabadít fel, amelyeken aztán nem tud uralkodni. A bonyolultság élménye sokakban megzavarta a felelösség érzetét. Az erkölcsi reflexió szempontjából sokan nem a vallási vagy világnézeti, hanem a természettudományokat illető agnoszticizmus álláspontjára helyezkednek, mondván: a világ minden öszszefüggését tökéletesen úgysem ismerhetjük, a tudományok minden felfedezése új kérdéseket vet fel. Ezért cselekvéseink igazi, teljes hatásrendszerét sem láthatjuk át, így értük teljes értelemben felelősséget sem vállalhatunk (vö. Erdő, 2007, 35-43.).

Ehhez a lehangoló érzethez járul gyakran a tehetetlenség élménye is. Nem is csupán a magasabb emberi szempontok érvényesítése területén, hanem például a környezetszennyezés vonatkozásában is gyakran sikerül világosan és nagy egyetértéssel megjelölni a problémákat. Sokszor megoldásuk vagy kezelésük módját is meg lehet határozni. Mégis, nem egyszer azt tapasztaljuk, hogy a felismert szükségszerüséghez a gazdaság müködése nem igazodik, hogy a meghatározott időn belüli profitszerzés logikája akadályozza ezeknek a veszélyeknek az elhárítását. Mintha valamiféle forgószél sodorná az emberiséget.

Ez a fajta lesújtó élmény, különösen a válságok hatására, néha átcsap a gazdasági cselekvéssel kapcsolatos közgondolkodásra is. Az átlagember a gazdaság müködését is - nem kis részben a globalizáció következtében - olyan bonyolultnak érzi, hogy rászokik a felelősséget elutasító, rövid távú gondolkodásra.

Az Egyház társadalmi tanítása az egyes ember és az emberiség teljes értelemben vett javát tartja szem elött. Ezért beszél az emberi méltóságról, különösen a munka összefüggésében, ahogyan II. János Pál pápa teszi például Laborem exer- 
cens kezdetủ enciklikájában (15. pont) (II. János Pál, 2005a, I/146-147.). Hangsúlyozza, hogy az emberi munka nemcsak a gazdaságra irányul, hanem személyes értékekkel is jár. Ugyanígy a gazdaságban sem elegendő a pénzügyi nyereség növelésére, valamint a termékek fölötti rendelkezésre és a hatalom kiterjesztésére törekedni, hanem tiszteletben kell tartani az emberi személy méltóságát is. Ez azonban ismét csak teljesebb emberképet kíván. Manapság gyakorivá vált az ember méltóságáról olyan értelemben beszélni, hogy fájdalomtól mentes állapotban legyen, esetleg tiszta körülmények között. Eredendően azonban a szónak bibliai értelme van. A teremtéstörténetnek arra a kijelentésére épül, hogy Isten az embert saját képére és hasonlatosságára alkotta. Az emberi értelem, az emberi szabadság és az örök életre szóló hivatás ennek a méltóságnak a megnyilvánulása. Ebben az értelemben a gazdasági kényszerek egyoldalú fokozása erkölcsileg aligha igazolható. Hasonlóképpen nem igazolható a gazdasági vagy politikai célok érdekében történő manipuláció, amely az emberi tudatot úgy befolyásolja, hogy megkerüli, kizárja a szabad mérlegelést. Az agresszív reklám például néhol szinte a kultúra központi formanyelveként jelenik meg, és már nemcsak a fogyasztói magatartást, hanem a politikai vagy világnézeti viselkedést is befolyása alá vonja. Ezek és hasonló tapasztalatok alkalmasak arra, hogy sokakban a tehetetlenség érzését keltsék fel, ami ismét csak önfeloldozást jelent a morális követelmények alól.

Ebben az összefüggésben a katolikus teológia évtizedekkel ezelött fölvetette már a strukturális bün kategóriájának kérdését. Eszerint a társadalom müködésébe épült és az erkölccsel ellenkező vagy annak érvényesülését kiszorító struktúrák mintegy strukturális bünt alkotnak, amely ránehezedik egyénre és társadalomra. Erre a helyzetre egyes teológiai kísérletek megoldásként a forradalmi teológiát javasolták, amely szerint a viszonyok erőszakos átalakítása, vagyis a forradalom, társadalmi szinten a megtérés szinonimája lehetne. Ezt azonban a hivatalos egyházi tanítás nem fogadta el, mégpedig nem csupán kétes politikai következményei miatt, hanem elsősorban azért, mert a bün a szó szoros értelmében egyéni, személyes emberi cselekedet, nem pedig kollektív valóság. Ugyanakkor kétségtelen, hogy a közösség működését is súlyosan befolyásolhatja. Ezért az Egyház társadalmi tanításának 2004-ben kiadott kompendiuma részletesen beszél a „bün struktúráiról” (119., 193., 232., 446. és 566. pont). A bün drámájáról szólva ez a szentszéki dokumentum kijelenti: „A bün misztériuma kétfajta sebet okoz: az egyik magában a bünösben jelenik meg, a másik a felebaráthoz való viszonyában. Ezért beszélhetünk személyes és társadalmi bünről: bizonyos szempontból minden bűn személyes bün, más szempontból pedig mindegyik társadalmi bün, annyiban és azért, mert társadalmi következményei is vannak" (117. pont) (Az Igazságosság és Béke Pápai Tanácsa, 2007). A felebarát említése ebben az összefüggésben egy sajátosan mai problémára is felhívja a figyelmet. Korunk embere, talán részben az új kommunikációs formák és a virtuális valóság hatására is, egyre inkább individualizálódik. Egyre gyakoribb a névtelen egyedként való egymás mellett élés. Az ember 
mindennapjainak egyre kisebb része zajlik eleven közösségben. Ezért mondják egyes szerzők, hogy a mai ember mellől eltűnt a felebarát. Nehezen tudjuk érzékelni, hogy kit és hogyan szeressünk magunk körül, kinek mire van szüksége, és mi válik javára. Sokkal könnyebb egy képernyőn megjelenő számlaszámra pénzt utalni, vagy telefonhívás díjával segíteni valamilyen célkitüzést.

A bün struktúráiról szólva az Egyház társadalmi tanitásának kompendiuma külön utal a gazdasági vonatkozásokra. Kijelenti: ,az Isten akaratával, valamint az embertárs javával ellentétes cselekedetek és magatartások, továbbá az ezek által gerjesztett struktúrák ma döntően kétfélék: »Az egyik a profitra való kizárólagos törekvés, a másik a hatalomvágy, amely saját akaratát törekszik rákényszeríteni másokra, éspedig [...] bármi áron «" (119. pont) (Az Igazságosság és Béke Pápai Tanácsa, 2007, 78.; II. János Pál, 2005c, I/563. n. 37.).

Mindezek fényében azt látjuk, hogy nem pusztán egy sajátosan szakmai logikát követő gazdasági cselekvés áll szemben az ember magasabb szükségleteit is tiszteletben tartó etikai értékelés igényével, hanem a gazdasági észszerüséget emberi ösztönök (például: birtoklási vágy, hatalomvágy) szolgálatába állító és a valóság többi részétől elszigetelő emberi magatartás egy másik emberi hozzáállással, amely magának az embernek és a valóságnak tágabb horizontját tartja szem elött. A kétféle szemlélet különbözősége megmutatkozik a gazdasági tevékenység céljának és eszközeinek megválasztása során is.

\section{A GAZDASÁGI RENDSZEREK AZ EGYHÁZ TÁRSADALMI TANITTÁSÁNAK FÉNYÉBEN}

Az emberi cselekvés elsődleges céljainak megvalósítását olyan mozgástér segítheti, amelynek gyakorlati kereteit az egyes gazdasági rendszerek jelölik ki. Éppen ez az az ismérv, amely szerint az Egyház társadalmi tanítása ezeket a rendszereket minősíti. A Quadragesimo anno-ban XI. Piusz pápa a társadalom keresztény helyreállításáról is szól az evangélium szellemében (149. pont) (vö. Duchini, 2004, 283.). Tehát a 20. század közepéig elsősorban a gazdasági élet szabályozó elveinek múködésében látták az erkölcsi követelmények érvényesítésének biztosítékát. XII. Piusz pápa azonban a szabadság elvének jegyében azt hangsúlyozta, hogy az Egyház nem utasít el kategorikusan bizonyos kormányzati formákat, feltéve hogy azok alkalmasak a polgárok javának szolgálatára, és az egyénnek megadják azt a tiszteletet és azt az életlehetőséget, amelyet a személy méltósága megkíván (vö. Duchini, 2004, 283.). XXIII. János pápa a Mater et magistra-ban (51. pont) (XXIII. János, é. n., 116.) a gazdasági világot az egyes polgárok egyéni vagy egymással társult kezdeményezéséből fakadó alkotásnak nevezte. Ebben az optimista megközelítésben sem merült azonban feledésbe, hogy az üdvösség és a teljes szabadulás a maga egészében nem ezen a világon érkezik el, hanem csak az eljövendőben (II. Vatikáni Zsinat, 1975, 
40-45.). II. János Pál pápa továbbmegy ennek a gondolatmenetnek a kifejtésében. Szerinte az Egyház nem részesíti előnyben egyik vagy másik gazdasági modellt, feltéve hogy azok kellően tisztelik az ember méltóságát, és megadják a szükséges lehetőséget arra, hogy az ember teljesítse küldetését a világban (II. János Pál, 2005c, I/565. n. 41.; vö. II. János Pál, 2005b I/799. n. 43.). Az egyházi társadalmi tanítás tehát a közgazdaságtan és a társadalomtudományok eredményeit nem kívánja figyelmen kívül hagyni, azonban saját ítéletet alkot, és felszólítja az egyes embert is, hogy keresse a közjó előmozdításának lehetőségét, hiszen a hatékony gazdasági rendszerek a különböző történelmi körülmények keretein belül születnek, ám nem automatikusan, hanem felelösségteljes emberek cselekvésének eredményeként, akik a problémákat társadalmi, gazdasági, kulturális összefüggéseikben vizsgálják, és így kívánják megoldani (vö. II. János Pál, 2005b, I/799. n. 43.). Ez a megállapítás pedig a mai körülmények között a kölcsönös összefüggés globális szövedékében is a teljes hatásrendszer figyelembevételére helyezi a hangsúlyt.

Itt térünk vissza a bonyolultság problémájához. Igaz, hogy a rendkívül gyorsan fejlődő informatika olyan tömegü adat gyors kezelését teszi lehetővé, amelyröl korábban nem is álmodhatott az emberiség, a rendszer adta válaszok mégis az általunk feltett kérdésektől függenek. Tehát nekünk, embereknek kell újra és újra megküzdenünk azért, hogy az összefüggések rendszerében olyan szempontok is megjelenjenek, amelyek az emberi méltóság, szabadság és a legteljesebb, legnemesebb értelemben vett közjó érvényesülésére vonatkoznak. Ezeknek a kérdéseknek és válaszoknak a beépítése a gazdasági döntéshozatalba, sőt a gazdasági rendszerek struktúráiba, olyan feladatnak látszik, amelynek megoldásán a gazdasági működés erkölcsi minősége és végső soron a földön az emberhez méltó élet - vagy egyáltalán az élet - lehetősége múlik. Ezért hangsúlyozza a 2009-es Afrika-szinódus, hogy a legjobb globalizáció a szolidaritás globalizációja (Sinodo dei vescovi, 2012, nr. 1146.).

\section{AZ ERKÖLCSI REFLEXIÓ ÚJ LEHETŐSÉGE}

A kihívás komolyságát fokozza az informatikai forradalom hatása az erkölcsi tudatra és az emberi cselekvésre. Kétségtelen tény, hogy a világhálóval nem csupán a tömegtájékoztatás vagy az ismeretszerzés egy újabb eszköze jelent meg, hanem a valóságnak egy új rétege, új szintje. Ha Arnold Gehlen azt írhatta, hogy az emberi beszéd visszahatott a fogalmi gondolkodás fejlődésére, és ezzel az általunk felfogott benyomások tömegében úgy segítette eligazodásunkat, hogy a fogalmakban megvalósuló elvonatkoztatással tehermentesítést hajtott végre, akkor ma hasonló horderejú változás körvonalai rajzolódnak ki. A fogalmak sajátos jellegủ létezéséről a görög filozófusok ideatana után a középkori filozófiában az 
arisztotelészi örökséget mintegy felszabadító Aquinói Szent Tamás mérsékelt realizmusa vázolt fel sajátos elképzelést. A fogalmak eszerint nem csupán nevek, hanem valamilyen sajátos valóságuk van. Ez a sajátos típusú fogalmi valóság, ennek módszeres kezelése adott nagy lendületet a természettudományok újkori fejlődésének. Ha a fogalmak világa is egy sajátos szintű valóságot hordoz, akkor a világháló által megjelenített virtuális valóság a maga új típusú tehermentesítő funkciójával szintén sajátos értelemben vett realitásként jelentkezik. Ha a korábbi etikai gondolkodás a fogalom-ítélet-következtetés pilléreire építő logika mentén ragadta meg az egyes helyzetekben lehetséges emberi magatartások értékét, akkor az újabb szintű informatikai tehermentesítés világában is benne rejlik a bonyolultabb valóságra való, magasabb szinten szimbolikus erkölcsi reflexió lehetősége. A rendszergazda pedig maga az ember. Nekünk kell keresnünk az egyre bonyolultabb valóságok részleteiben is az emberi teljességhez és így végső soron Isten akaratához való helyes kapcsolódás lehetőségét.

Erre a nagy problémára egyetlen és végleges megoldás valószínüleg nem létezik. Állandó, elkötelezett és elszánt törekvésre van szükség a gazdaság minden szereplöje, a társadalom minden tényezője, végső soron minden erkölcsileg tudatos ember részéröl.

\section{IRODALOM}

II. János Pál (2005a): Laborem exercens. In: II. János Pál megnyilatkozásai. Pápai dokumentumok 1978-2005. I. (szerk. Diós I.) Budapest, Szent István Társulat, 135-186.

II. János Pál (2005b): Centesimus annus. In: II. János Pál megnyilatkozásai I. (szerk. Diós I.) Budapest: Szent István Társulat, 761-812.

II. János Pál (2005c): Sollicitudo rei socialis. In: II. János Pál megnyilatkozásai I. (szerk. Diós I.) Budapest: Szent István Társulat, 533-576.

II. Vatikáni Zsinat (1975): Const. past. Gaudium et Spes. In: Cserháti J. - Fábián Á. (szerk.): A II. Vatikáni Zsinat tanitása. A zsinati döntések magyarázata és okmányai. Budapest: Szent István Társulat, 446-509., http://uj.katolikus.hu/konyvtar.php?h=16

XI. Piusz (é. n.): Quadragesimo Anno. In: Tomka M. - Goják J. (szerk.): Az Egyház társadalmi tanitása. Dokumentumok. Budapest: Szent István Társulat, 57-103.

XXIII. János (é. n.): Mater et magistra. In: Tomka M. - Goják J. (szerk.): Az Egyház társadalmi tanitása. Dokumentumok. Budapest, Szent István Társulat, 107-159.

Az Igazságosság és Béke Pápai Tanácsa (2007): Az Egyház társadalmi tanitásának kompendiuma. (Szent István Kézikönyvek 12), Budapest: Szent István Társulat, http://www.vatican.va/roman_curia/pontifical_councils/justpeace/documents/rc_pc_justpeace_doc_20060526_compendio-dott-soc hu.html

Duchini, Francesca (2004): Economia. In: Università cattolica del Sacro Cuore. Centro di ricerche per lo studio della dottrina sociale della Chiesa: Dizionario di Dottrina Sociale della Chiesa. Scienze sociali e Magistero. Milano: Vita e Pensiero, 280-285.

Erdő Péter (2007): Erkölcs egy bonyolult világban. Háború, tudomány, kereszténység. Magyar Sion. Új folyam, 1, 35-43., http://epa.oszk.hu/01300/01397/00001/pdf/2007_1_035-043.pdf 
Erdő Péter (2013): Gazdaság és erkölcs. Előadás a Budapesti Corvinus Egyetemen, 2013. február 14-én. In: Köz-Gazdaság. Tudományos füzetek. A Budapesti Corvinus Egyetem Közgazdaságtudományi Karának kiadványa, 8/2 (2013. május) 62-69. https://goo.gl/j17heE

Sinodo dei vescovi (II. Assemblea speciale per l'Africa) (2012): Elenco finale delle proposizioni. Roma, 24. ottobre 2009, prop. 31.; Enchiridion Vaticanum 26, Bologna, 797-843., nr 10591216. http://www.vatican.va/roman_curia/synod/documents/rc_synod_doc_20091023_elenco-prop-finali_it.html 